\title{
GENEESKUNDIGE ETIEK IN DIE GRIEKS-ROMEINSE TYD
}

\author{
L Cilliers \& F P Retief (Universiteit van die Vrystaat)
}

\begin{abstract}
Die wortels van moderne geneeskunde kan teruggevoer word na die Klassieke era van Griekeland en Hippokratiese geneeskunde in die besonder. Die Corpus Hippocraticum word vandag veral onthou vir die besondere etiese kode wat daarin opgeneem is. In hierdie bydrae word aspekte van geneeskundige etiek in die Grieks-Romeinse era in oorsig geneem.
\end{abstract}

\section{Die pre-klassieke era}

Griekse geneeskundige geskiedenis vind sy oorsprong in die epiese verhale van Homeros, waar siektes aan optrede van die gode toegeskryf is. Genesers in hierdie era was van uiteenlopende aard, van priesters en ander magiese genesers tot geneeshere wat volgens die wetenskaplike kennis van die dag gepraktiseer het. Thales van Milete (7de eeu v.C.) en Anaximander van Milete (6de eeu v.C.) het as filosowe verklarings vir die ontstaan van die kosmos en die wetenskap gesoek, maar Pitagoras (570-489 v.C.) kan as die eerste ware filosoof-geneesheer beskou word, met sy bydraes wat 'n direkte impak op geneeskunde gehad het. Benewens uitstaande bydraes in die wiskunde, het Pitagoras o.a. aan reïnkarnasie van die siel geglo. Deur 'n gebalanseerde leefwyse en respek vir die lewe kon 'n gunstige voortbestaan vir die siel na die dood verseker word; die etiese implikasies van hierdie siening het geneeskundige optrede lank na Pitagoras se dood beïnvloed. Aborsie, eutanasie en enige vorm van doelbewuste vergiftiging, sowel as chirurgie is belet en 'n streng verantwoordelikheidskode teenoor die leermeester is gehandhaaf. Hy en sy leerling, Alkmaion, was waarskynlik ook verantwoordelik vir die formulering van die teorie van die vier liggaamshumore wat tesame met spesifieke elemente en ander fisiese eienskappe gesondheid sou reguleer. Alhoewel heeltemal fiktief, is hierdie teorie vir meer as twee millennia as dogma aanvaar. As "rasionele" verklaring vir siekte het dit geneeskunde ook progressief ontkoppel van mistieke en mantiese invloede (Major 1954:102-115; Godderis 1997:234-237).

\section{Die Klassieke Griekse en Hellenistiese eras}

\subsection{Die Corpus Hippocraticum}

Gedurende die 5de eeu v.C., die Goue Eeu van Atene, het 'n verskeidenheid filosowe soos Anaxagoras, Demokritos, Diogenes en veral Empedokles o.a. voortgebou aan 'n geneeskunde-stelsel wat progressief bevry was van bygeloof en religie, selfs van onvanpaste filosofie. Maar dit was op die eiland Kos onder leiding van Hippokrates (en in 'n mindere mate op die naburige eiland Knidos) dat rasionele geneeskunde gebou op wetenskaplike beginsels soos toe verstaan, begin blom het (Sherwin-White 1978:263-273). 'n Groot aantal mediese werke wat later byeengebring is in 'n versameling bekend as die Corpus Hippocraticum, is dan ook in hierdie tyd geskryf (daar is egter vandag meningsverskil oor die presiese aantal werke wat wel vir insluiting kwalifiseer). Van die 69 afsonderlike werke waaruit die Corpus waarskynlik bestaan, is 47 heel moontlik in die Hippokratiese era (5de en 
4de eeue v.C.) geskryf (minder as twaalf deur Hippokrates self) waarvan 41 uit die Kosgemeenskap en ses uit Knidos gekom het; minstens agt werke (dalk meer) dateer waarskynlik uit die Hellenistiese tyd en sewe uit die Christen-era (Jouanna 1999: Appendix 1 and 3). Anders as in Egipte en Mesopotamië waar geneeskunde-norme permanent gekodifiseer was, het die Corpus vanuit deurlopende bespreking gegroei, en latere werke het inderdaad inhoudsgewys van vroeëre werke verskil. 'n Wye verskeidenheid onderwerpe is bespreek met klem op kliniese waarnemings oor, en hantering van, siektetoestande, maar ook sienings oor gesondheid en die omgewing (Edelstein 1987: 326-331). Bespiegeling oor die ontstaan van siektes is weens onkunde oor veral anatomie en fisiologie vandag van minder waarde, maar daar is ook treffende gedeeltes oor 'n gepaste etiese kode, waarvan die Hippokratiese Eed waarskynlik die bekendste is. Alleen die gedeeltes oor beroepsetiek word nou verder bespreek.

\subsection{Die Hippokratiese Eed}

Die Hippokratiese Eed kan soos volg saamgevat word (Adams 1985: 779-781):

Daar word by die gode (o.a. Apollo en Asklepios) gesweer dat die geneeskunde-beroep gepas beoefen sal word. Leermeesters sal geëer, selfs finansieel ondersteun word; hul kinders sal versorg en kosteloos onderrig word; onderrig sal ook gegee word aan almal wat daarvoor goedgekeur is, maar aan niemand anders nie.

Siekes sal so doeltreffend moontlik behandel en nooit benadeel word nie. Geen gifstof sal op versoek beskikbaar gestel, of aborsie aangebring word nie. Operasies sal nie uitgevoer word nie maar oorgelaat word aan diegene wat daarvoor opgelei is.

Daar sal kuis en godsdienstig gelewe word.

Kontak met pasiënte sal altyd tot hul voordeel geskied en niemand (ook nie slawe nie) sal benadeel word nie - in besonder sal seksuele kontak met pasiënte vermy word. Persoonlike inligting wat van siekes verneem is, sal nie na ander oorgedra word nie.

Mag uitlewing van hierdie Eed voorspoed en verering bring, maar mag verbreking van die Eed tot mislukking en benadeling lei.

Daar is onsekerheid oor die presiese oorsprong en gebruik van hierdie dokument. Dit is waarskynlik in die Hippokratiese era op Kos opgestel, maar daar was heel moontlik latere toevoegings, selfs vanuit die Pitagoreïese kultus met sy sterk klem op behoud van lewe en menswaardigheid. Dit is baie onwaarskynlik dat van alle aspirant-geneeshere op Kos verwag is om die Eed af te lê. Dit is selfs moontlik dat die Eed eers in die Christelike era bekend en populêr geword en oor die daaropvolgende eeue meer invloedryk geraak het as in sy ontstaanstyd (Van Hooff 1999:122-127; Longrigg 1998:105-6).

\subsection{Etiese riglyne in ander werke van die Corpus Hippocraticum}

Verskeie van die ander werke in die Corpus Hippocraticum bevat ook etiese riglyne wat soms verbasend modern aandoen: 


\subsubsection{Geneesheer-pasiënt-verhouding}

Die pasiënt plaas homself in die hande van sy geneesheer, wat dan ook sy vertroue moet wen (Geneesheer c.1). Die geneesheer moet homself telkens voorberei op die besoek van sy pasiënt sodat hy in beheer is tydens die konsultasie. Hy moet sy optrede aanpas by die betrokke pasiënt se persoonlikheid - party wil praktiese advies hê, nie lang besprekings en redenasies nie. Hierdie antisipering van die pasiënt se behoeftes is belangrik vir goeie resultate, en moet aangeleer word. Die arts se optrede in die algemeen moet van pas wees hoe hy die kamer binnekom, die graad van outoriteit wat uitgestraal word, sy fatsoenlikheid, kalmte en beskeidenheid. Maar gepaste afkeur van steurnisse wat mag voorkom is in orde, en hy moet voorbereid wees vir onverwagte gebeure en besware wat mag opduik. Die geneesheer moet altyd toeganklik wees - 'n bot, afsydige persoon is van min waarde vir die sieke. Hy moenie onnodig oor homself praat nie, en nie oor ander skinder nie, maar net sê wat nodig is, en nie deur oordadige optrede aandag soek nie (Dekorum cc. 7, 11, 12, 16). Hy moenie skroom om 'n ander geneesheer in konsultasie te roep nie - dis geen skande nie. Selfs hy wat baie kennis het, het ook tekortkominge (Voorskrifte c. 7).

Wat vergoeding betref is daar die advies dat die arts nie sy konsultasie moet begin met 'n bespreking van tariewe nie - die pasiënt sal dadelik vermoed dat die dokter hom in die steek sal laat indien hy nie kan betaal nie. Sulke kommer benadeel die pasiënt, veral die akuut siekes. Die dokter moet 'n konsultasie beskou as 'n geleentheid om sy reputasie te verhoog, nie om ryk te word nie. Hy moet altyd die pasiënt se finansiële vermoëns in ag neem en soms sy dienste gratis lewer. Maar 'n minder gegoede pasiënt moenie in die verleentheid gestel word nie. Hy moet bv. sê dat hy nie geld vra nie, uit dankbaarheid vir 'n vorige guns aan hom bewys, en streng wees met 'n geneesde pasiënt, maar nie geld dwing uit sterwendes nie (Voorskrifte c. 4 en 6).

Opvolgbesoeke is belangrik en die ondersoeke moet telkens volledig wees. Situasies mag verander, en daar moet geleentheid wees om verkeerde interpretasies en misverstande reg te stel. So leer die arts die pasiënt ook deeglik ken en verhoed dit foutiewe optrede wat tydens kritieke tye in die siekte-verloop lg. se dood mag beteken. Onthou ook dat die pasiënt nie altyd volledig saamwerk nie - hulle jok dikwels oor die neem van onaangename medikamente en ander behandeling. As hulle dan sterf, bly hul nalatigheid onvermeld, maar word die geneesheer geblameer (Dekorum cc. 13 en 14). Pasiënte moet op 'n kalm wyse aangemoedig word en hul aandag van onaangename sake afgelei word. Dis soms gerade om aspekte van die siekte van die pasiënt te verberg. By tye is dit ook nodig om die pasiënt ferm te vermaan en te berispe (Dekorum c. 16).

Die geneesheer word ook geadviseer om sensitief te wees teenoor vreemdelinge. Vriendelike optrede sal soms in eie reg 'n sieke laat beter voel. Hy moet siekes behandel, maar ook gesondes help om gesond te bly (Voorskrifte c. 6).

Daar moet 'n noue band van vertroue tussen pasiënt en geneesheer wees. Die dokter mag nie misbruik makk van sy vertrouensposisie in sy kontak met maagde, vroue en kosbare besittings van andere nie (Geneesheer c. 1). 


\subsubsection{Die geneesheer as persoon}

Ten einde geneeskunde te bemeester is inherente vermoë essensieel - daarsonder is alle strewe verniet. Fluksheid en beskikbare tyd vir voldoende opleiding in 'n gepaste milieu by iemand wat die vermoë het om toepaslike onderrig te gee, is dan nodig. Opvoeding vanaf die kinderjare is belangrik. Waar dinge reg verloop, is onderrig in die geneeskunde maklik (Die Wet c. 2).

Die geneesheer behoort 'n gesonde voorkoms te hê en in 'n goeie gesondheidstoestand te wees, want dis soos die natuur dit verlang. Iemand wat nie in 'n goeie fisiese toestand is nie, sal deur gewone mense beskou word as nie geskik om na hulle om te sien nie. Hy moet skoon wees en welgekleed met gepaste parfuum. Uitspattige duur kleredrag en hooftooisel, en 'n eksotiese parfuum, toon gebrek aan ondervinding en sal mense laat skinder. Iets buitengewoons mag egter soms in goeie smaak wees. Hy moet daarna streef om 'n goeie reputasie op te bou (Dekorum c. 3, Voorskrifte c. 10, Geneesheer c. 1). Hy moet homself nie verwaarloos nie (Voorskrifte c. 6).

Daar moet gestreef word na 'n morele, gedissiplineerde leefwyse en eerbare karakter sodat optrede teenoor ander telkens opreg en vriendelik sal wees. Voorbarige en haastige optrede maak 'n swak indruk. Die geneesheer moet versigtig besin oor sy reg van vrye optrede. Sy gesigsuitdrukking behoort simpatiek en nie oormatig streng te wees nie, want dit suggereer hardkoppigheid en skoorsoekerigheid. Maar andersyds kom hy wat oormatig lag en opgewek is, weer vulgêr voor - en dít moet vermy word. Wees altyd regverdig - dis 'n groot sosiale bate (Geneesheer c. 1).

'n Geneesheer moet sy kollegas nie uittart of met hulle rusie soek nie. Jaloesie is 'n teken van swakheid en dit hoort op die markplein, nie in die spreekkamer nie (Voorskrifte c. 8). Om lesings te gee bloot omdat die geneesheer dit geniet om voor groot gehore op te tree, is nie aan te beveel nie. En aanhalings van die digters moet vermy word - oormatige gebruik van aanhalings verklap 'n gebrek aan insig (Voorskrifte c. 12).

\subsubsection{Die geneesheer en sy beroep}

Die lewe is kort en die wetenskap lank van duur. Geleenthede is kortstondig, eksperimentering gevaarlik en oordeel moeilik. Die geneesheer moenie alleen dit doen wat aangewese is nie; hy moet ook die vertroue van sy pasiënt en assistente wen en tersaaklike eksterne faktore kan akkommodeer (Aforismes 1.1).

Die geneeskunde is 'n lewenslange leerproses en strewe na 'n wetenskaplike milieu. Harde werk is nodig. Leer dit wat van praktiese waarde is (Die Wet c. 2). Die geneesheer moet volwaardig strewe na wat edel is in die beroep. Hy moet homself toewikkel in sy wetenskap, dit bewaar, praktiseer, handhaaf en oordra aan ander. Dit moet iets glorieryks wees wat jaloers bewaar word tussen die betrokkenes, en dié wat dit beoefen, moet sorg dat dit deur ouers en kinders in ere gehou word. Dit alles dra by tot 'n goeie reputasie, fatsoenlikheid en wysheid, wat die geneeskunde en die wetenskap in die algemeen moet kenmerk (Dekorum c. 18).

Die arts word ook aangespoor om van sy dienste gratis te lewer. Waar daar liefde vir die mens is, is daar ook liefde vir die wetenskap (Voorskrifte c. 6).

In die hantering van siektes moet daar gestreef word na twee dinge - om te help, of om ten minste nie te benadeel nie. Daar is drie faktore in die genesingsproses : die siekte, die pasiënt 
en die dokter. Die dokter hanteer die genesing, en die pasiënt moet met die dokter saamwerk ten einde die siekte te bestry (Epidemies 1.11).

Dit is beter om nie verborge kankers te behandel nie. Onder behandeling sterf pasiënte vinnig, maar sonder behandeling leef hulle langer (Aforismes 6.38). Geneeshere word soms daarvoor kwalik geneem dat hulle hul nie oor pasiënte wat aan ongeneeslike siektes ly, ontferm nie, maar moeite doen met dié wat in ieder geval sou herstel (Die Kuns c. 8). Die geneesheer moet siektes bekamp en lyding versag maar nie behandeling instel wat dan deur die siekte oorweldig sal word nie (Die Kuns c. 3).

\subsection{Opmerkings oor mediese etiek in ander outeurs}

Sokrates en Plato, tydgenote van Hippokrates, het as filosowe 'n groot belangstelling in geneeskunde getoon. Plato was die eerste skrywer om na Hippokrates as persoon te verwys (Protagoras 311b en c), en het drie funksies in die menslike natuur onderskei - die rede (in die brein gesetel), die gees (in die hart) en die eetlus (in die lewer). ). In sy Timaios het Plato heelwat oor die verband tussen geneeskunde en die filosofie geskryf. Lloyd (1950:39) wys inderdaad uit dat die Anonymus Londinensis in die gedeelte oor Meno se geskiedenis van geneeskunde (waarskynlik laat 4de eeu n.C. geskryf), meer aandag aan Plato as aan Hippokrates wy. Plato het die Hippokratiese geneeskundige etiek grotendeels onderskryf, en 'n band van philia (vriendskap, toegeneentheid) tussen geneesheer en pasiënt aanbeveel (Lysis 217a). In die Corpus Hippocraticum self het die filantropie-konsep selde voorgekom, maar Plato het klem geplaas op 'n hoëre sin in die lewe as fisiese gesondheid. Hy het uitgewys dat gesondheidsorg tussen die sosiale strata van Atene ongelyk was, met die beste versorging van rykes en die swakste diens vir slawe. Goeie diens kon alleen geskied waar die pasiënt die geneesheer vertrou, en lg. daarin kon slaag om deur oorreding eg. van sy siektetoestand te oortuig. Die geneesheer moet die belange van die staat voorop stel wanneer oor behandeling besluit word. Siekes wat 'n belangrike rol in die staat speel, moet voorkeurbehandeling kry. Die ideale arts se grootste verantwoordelikheid is dan ook teenoor die staat (Godderis 1997:251-256). Dit is heeltemal in orde vir 'n geneesheer om uit sy beroep geld te verdien (Rep. I.342d). In sy Simposium beweer Plato dat dit goed is om goeie mense te help, maar slegtes moenie genees word nie (186b-c).

Aristoteles, filosoof van die 4de eeu v.C., het 'n invloedryke bydrae gelewer tot gesondheid en lewe in die algemeen - beide oor liggaamstrukture en die psige (Porter 1997:64-6; Godderis 1997:247-8). Die geneesheer se suksesse het volgens hom berus op toegepaste philotechnia - 'n liefde vir die wetenskap wat sy hand gesterk het om die pasiënt se natuurlik neiging om gesond te word, te bevorder. Hy het Hippokrates in sy werke aangeprys. In pas met aanbevelings van Aforismes 6.38 en Die Kuns c. 3, het Aristoteles ook aanbeveel dat dié wat nie genees kan word nie, aan hulself oorgelaat moet word (Eth. Nic.1165b) .

Erasistratos, Alexandrynse geneesheer van die Hellenistiese era, het volgens Soranos gesê dat dit die ideaal is dat 'n geneesheer sal presteer beide in sy beroepsvaardighede en morele optrede. Maar as hy iets moet kortkom, is dit beter as dit beroepskennis is - 'n morele geneesheer sonder kennis is beter as 'n immorele een met kennis. Morele probleme korrupteer selfs die beste beroepswaardes (aangehaal deur Edelstein 1987:334). 


\section{Die Romeinse era}

\subsection{Opmerkings oor mediese etiek deur Cato, Cicero en Plinius die Ouere}

Met die aankoms van die eerste Griekse geneeshere in Rome, veral vanaf die 3de eeu v.C., het die Hippokratiese geneeskunde en etos die primitiewe geneeskunde van vroeë Rome, gebaseer op godsdiens en bygeloof, geleidelik verplaas. Alhoewel die meeste Romeine hulle aanvaar het, het sommige gesiene burgers die Griekse invloede ten sterkste afgekeur en veroordeel (Major 1954:162). Cato die Ouere (2de eeu v.C.), wat die tradisionele Romeinse geneeskunde bevredigend gevind het, was in beginsel teen die nuwerwetse Griekse geneeskunde, maar nie spesifiek teen sy etiek nie (aangehaal deur Plin. HN XXIX.7.14). Cicero (1ste eeu v.C.) het Griekse geneeshere as blote handelaars eerder as gesiene beroepslui beskou, maar tog, soos Seneca (1ste eeu n.C.), sy eie geneeshere aangeprys (Cic. Ad Fam. 13.20; Sen. De Ben. 3.35.2; 6.15.4). Maar Plinius die Ouere (1ste eeu n.C.) het Griekse geneeshere skerp gekritiseer, en in die besonder hul etiese en morele waardes $(H N$ XXIX.8-28). Nutton (1988:VIII.43-4) toon aan dat hoewel daar elemente van waarheid kon gesteek het in van Plinius se bewerings dat Griekse artse ondoeltreffend, immoreel en geldgierig was, sy motivering oorwegend uit diepe vooroordeel teenoor enigiets Grieks gespruit het.

\subsection{Scribonius Largus}

Beduidende bydraes tot geneeskundige etiek is ook gelewer deur ander invloedryke medici. Scribonius Largus (1ste eeu n.C.) was geneesheer in die tyd van die keisers Tiberius en Claudius, en het laasgenoemde op 'n militêre ekspedisie na Brittanje vergesel. Net een van sy werke, Compositiones ('n versameling farmakologiese resepte), het vir ons bewaar gebly, en die voorwoord hiervan, in die vorm van 'n brief aan sy weldoener Callistus, bevat besondere sienings oor geneeskundige etiek (Hamilton 1986:209-212; Major 1954:167-8). Hy verdedig die gebruik van geneesmiddels in die terapie van siektes, nadat sekere gesiene geneeshere en navolgers van Pitagoras die gebruik van alle geneesmiddels veroordeel en sektes soos die Pneumatici en Empirici dit weer lukraak misbruik het. Hy beskou dit as die morele plig van artse om kennis van geneesmiddels op te doen en dan beproefde middels, soos aangedui, te gebruik om lyding te versag. Geen middels mag aangewend word om iemand doelbewus te vergiftig of om aborsie aan te bring nie - nie eers by 'n vyand van die staat nie. Hy haal Herophilos aan wat gesê het dat geneesmiddels “die hande van die gode” is (Praef. 1).

Geneeshere moet onder morele verpligting staan om hul vakgebied so goed as moontlik te bemeester, en Scribonius voel dat daar 'n eed (soos dié van Hippokrates) afgelê moet word om die erns van die beroepsverpligtinge tuis te bring. Hy meen dat indien 'n geneesheer hierdie kode verbreek, hy soos 'n soldaat wat dros, deur die beoefenaars van die beroep verdoem moet word. En kritiek word daarteen uitgespreek dat die publiek nie hul geneeshere versigtig uitsoek nie - soos wanneer 'n kunstenaar bv. gesoek word om 'n portret te skilder. Geneeskunde is nie net 'n wetenskap nie, dis 'n beroep, ingestel om te genees en nooit skade te berokken nie. Die geneesheer mag nie gelei word deur 'n strewe na geld of roem nie, slegs die optimale beoefening van sy beroep ter bevordering van gesondheid. Ware humanitas (liefde vir die mensdom) moet die geneesheer rig. Hierdie voorwoord tot die versameling 
mediese resepte is 'n merkwaardige dokument vir 'n Romein van die 1ste eeu n.C. (Hamilton 1986:212-216).

\subsection{Cornelius Celsus}

Aulus Cornelius Celsus (1ste eeu n.C. ), die ensiklopedis, was nie 'n geneesheer nie, maar het in Efese wydlopende samevattings (in Latyn) van die kennis van sy tyd oor o.a. landbou, retoriek, krygskunde, filosofie, die regswetenskap en ook geneeskunde byeengebring. Slegs sy bydrae oor geneeskunde (De Medicina) het vir ons bewaar gebly. In die Prooemium van die werk raak Celsus aspekte van geneeskundige etiek aan. Hy vind dit nodig dat 'n studie van die teorie van geneeskunde altyd afgerond moet word met toepaslike praktiese ondervinding. Die goeie dokter is nie noodwendig 'n goeie redenaar nie - die ware kenner is dikwels 'n persoon van min woorde (Proem. 39). Dis waarskynlik onmoontlik om ooit alle kennis in pag te hê - deurlopende bespreking van teorie en praktiese ondervinding bring die antwoorde (Proem. 45). Die finale opdrag vir die arts is om siekes te help - hy mag nie moeilike behandeling weerhou omdat hy bang is sy eie reputasie lei skade as hy misluk nie (Proem. 49-52). Celsus meen geneeskunde het uit filosofie ontstaan, en Hippokrates het dit finaal daarvan ontkoppel (Proem. 8), alhoewel medies-filosofiese skole soos die Metodiste, Pneumatici, Empirici, ensomeer, steeds aktief was (Proem. 27 e.v.). Hy meen kontemporêre siektes het ontstaan uit luiheid en weelde wat nie in die ou tyd bestaan het nie - daarom is die nuwe geneeskunde nou nodig terwyl dit nie in vroeëre tye 'n rol te speel gehad het nie (Proem. 4-5). Celsus vind viviseksie, soos gedoen deur o.a. Herophilus in Alexandrië in die 3de eeu v.C., onaanvaarbaar (Proem. 74-75).

\subsection{Soranos van Efese}

Soranos van Efese (2de eeu n.C.), die grootste ginekoloog-verloskundige van die Oudheid, het in sy hoofwerk, Ginekologie, duidelike riglyne gegee oor die ideale vroedvrou, asook etiese norme verskaf vir die bedryf van verloskunde. Die vroedvrou, het hy gesê, moet geletterd wees en 'n stabiele persoonlikheid hê, asook 'n goeie geheue, werkywer en goeie gesondheid. Sy moet respek afdwing. Sy moet haar hande sag hou met gepaste salwe. Lang vingers (en kort vingernaels) sal haar werksopdrag vergemaklik, maar met baie oefening sal sy ook sonder eg. doeltreffend kan optree. Die goeie vroedvrou voer haar prosedures doeltreffend uit, maar die beste vroedvrou ken ook die onderliggende teorie, en is onderlê in alle aspekte van terapie, soos dieet, riglyne vir 'n gesonde lewenswyse, die gebruik van medikamente, en selfs chirurgie. Sy kan haar aanpas by die unieke andersheid van elke geval. Sy bly kalm en ewewigtig, hou by aanvaarde behandelingsbeginsels, skrik nie vir 'n noodtoestand nie en laat haar nie beïnvloed deur bygeloof of drome nie. Sy hoef nie noodwendig jonk te wees of alreeds kinders van haar eie te hê nie, maar moet te alle tye simpatiek wees en vertroue by haar pasiënte inboesem. 'n Stil geaardheid is verkieslik, want sy moet baie geheime deel. Sy moet nie geldgierig wees nie - dit mag veroorsaak dat sy 'n aborsie vir geld doen (Ginekologie I.3-5). 


\subsection{Galenos}

Galenos (2de eeu n.C.), die uitstaande geneesheer van die Romeinse era, het met sy uitgebreide sistematisering van geneeskundige kennis die denke in hierdie veld vir byna twee millennia oorheers. Hy het Hippokratiese geneeskunde sterk ondersteun maar ook 'n stuk filosofie bygetrek. In Die beste geneesheer is ook 'n filosoof som hy sy siening van etiek op, en bevestig dat toewyding aan die beroep, selfbeheersing, eerlikheid en afkeer van geldgierigheid, kernelemente in die soeke na ideale geneesheerskap was. Hy dring ook daarop aan dat inherente beroepsgedrewe moraliteit aangevul word deur 'n filosofies gedrewe moraliteit hoofsaaklik gebaseer op 'n kombinasie van Stoïsisme, Platonisme en die leerstellinge van Aristoteles. Galenos is terselfdertyd baie pragmaties oor geneeshere se motiverings om in die geneeskundige praktyk te wees. Die arts aanvaar dat hy siekes moet genees, maar die motivering hiervoor mag wees om geld te maak, om van sekere openbare verpligtinge vrygestel te word (soos veral in Griekse gemeenskappe die gebruik was), vir die eer van die beroep, of by sommige wel liefde vir die medemens (filantropie). Galenos het aanvaar dat heersers en rykes beter behandeling sal ontvang as armes en slawe, en riglyne in dié verband neergelê. Hy het pasiënte met 'n swak prognose nie weggewys nie. Hy was klaarblyklik 'n verwaande, eiegeregtige persoon wat sy eie prestasies aangeprys en dié van sy kollegas graag gekritiseer het. Hy het ook langdradig en dikwels wollerig geskryf, maar was tog 'n uitstaande wetenskaplike en denker wat o.a. aan 'n monoteïstiese god, die skepper van die heelal, geglo het, maar nie 'n Christen was nie (Cilliers \& Retief 2003:81-88).

\subsection{Apuleius en Libanios}

$\mathrm{Na}$ Galenos, en tot met die val van Rome in 476, het geen geneeshere blywende rigtinggewende bydraes tot geneeskundige etiek gemaak nie. Enkele nie-geneeshere se opmerkings is wel opgeteken. Apuleius (2de eeu) het in sy Metamorfose opgemerk dat medici ten alle koste dit vermy om aandadig te wees aan die dood van iemand, omdat hulle daarna strewe om lewens te red, nie te benadeel nie (Edelstein 1987:343). In die 4de eeu het die Griekse skrywer en retorikus, Libanios, in 'n roerende boodskap aan 'n jong geneesheer aan die begin van sy loopbaan, die basis van etiek uitgespel (vanuit 'n Stoïsynse perspektief). Praktiseer die beroep getrou, het hy gesê, en wees betroubaar. Wanneer 'n pasiënt jou roep, gaan dadelik en gee jou onverdeelde aandag aan die geval. Deel sy pyn en verligting beskou jouself as 'n vennoot in die siekte. Jy was bevoorreg om uitstekende opleiding te kry; ontwikkel nou 'n liefde vir die mensdom en word deel van 'n groot familie geneeskundiges broer van jou tydgenote, kind van die ouer artse en pa vir die jongeres. En as jy iemand sy pligte sien afskeep, onthou dat dit nie vir jou toelaatbaar is nie - wees vir die siekes wat die Dioskoeroi, die beskermgode van die matrose, vir lg. in gevaar is (Edelstein 1987:345).

Libanios het geleef toe die Christelike geloof reeds tot staatsgeloof in die Romeinse Ryk verhef is. Die Christendom het geneeskunde-etiek waarskynlik slegs indirek beïnvloed. Sterk ingestel op die genesende krag van die geloof, het vroeë Christene egter oënskynlik gemaklik met rasionele (sekulêre) geneeskunde saamgeleef. 'n Christen-geneesheer, Alexander van Frigië, het in die 2de eeu vir sy geloof 'n marteldood gesterf. Die besondere empatie van Christene vir siekes en andere in nood het teen die 4de eeu gelei tot die stigting van hospitale in die moderne sin van die woord. Mettertyd het spanning tussen die Grieks-Romeinse geneeskunde en streng Christene egter wel ontstaan toe laasgenoemde beweer het dat te veel 
vertroue op sekulêre geneeskunde eerder as die krag van God (en wondergenesing) geplaas word. In die tyd van Ciprianus en Anastasius van Sinai (3de eeu) is daar selfs gedebatteer of epidemies, in die lig van die kerklike dogma van die deug van lyding, inderdaad bestry mag word.

\section{Samevatting}

Die Corpus Hippocraticum bevat die wortels van geneeskunde-etiek in die Grieks-Romeinse era. Gebore uit standpunte van filosoof-geneeshere van die 6de en 5de eeue v.C. en gegiet tydens die kulturele opwelling van die Goue Eeu van Atene, het die Corpus in die loop van ongeveer vier eeue deur voortdurende gesprekvoering konkrete vorm aangeneem (Godderis 1997:235-260). Die dele daarvan met die sterkste deontologiese inhoud, nl. Die Eed, Voorskrifte, Dekorum en Die Geneesheer, is waarskynlik laat voltooi of bygevoeg - tydens die Hellenistiese tyd of selfs die Christen-era (Lloyd 1950:19; Edelstein 1987:328-329). Die kernbeginsels van geneesheer-etiek wat uitgespel is, was eenvoudig en eintlik tydloos: die geneesheer moes 'n deeglike beroepsopleiding deurloop waarna hy homself in onselfsugtige diens van die bekamping van siekte moes plaas; hy moes moreel lewe, hardwerkend, betroubaar en pligsgetrou wees, bedagsaam teenoor sy pasiënte optree en nie geldgierig wees nie. Maar geen geneesheer is gedwing om hierdie etiese kode na te volg nie. Die Hippokratiese etiek is tot in die 5de eeu n.C. grotendeels aanvaar (en uitgebou) deur geneeshere, filosowe en ander kenners wat oor die onderwerp geskryf het.

Die presiese rol van die Eed is onduidelik. Weens sy klem op die behoud van lewe, verbod op aborsie en respek vir die leermeester, word 'n Pitagoreïese inset vermoed. Waarskynlik die eerste antieke skrywers om na die Eed te verwys was Scribonius Largus (1ste eeu n.C.), en dit is moontlik dat die dokument eers in die Christelike era werklik bekend en populêr geword het (Godderis 1997:259; Edelstein 1987:331). Daar is geen bewys dat die Eed gereeld deur aspirant-geneeshere op Kos (of elders) afgelê is nie. Daar heers ook interpretasieprobleme oor sekere stellings in die dokument (Longrigg 1998:106; Van Hooff 1999:122127). Dit is onseker of die verbod op die beskikbaarstelling van gif die dokter verbied het om by selfmoord, eutanasie (of selfs meer sinister, by moord) betrokke te raak. Daar is getuienis dat beide aborsie en eutanasie in die Hippokratiese era wel as gangbaar aanvaar is. Dis ook onseker of die oorspronklike Griekse teks 'n algemene verbod op sekere chirurgiese prosedures plaas of slegs op persone wat nie spesifiek daarvoor opgelei is nie. Die gedeelte wat 'n besondere verantwoordelikheid teenoor leermeesters en hul kinders uitspel, val ook vandag vreemd op, maar oor die algemeen weerspieël die breë etos van toegewyde, onselfsugtige pasiëntediens en beroepstrots 'n uitgangspunt wat vandag nog steeds sterk aanklank vind. Die verbod op onderrig aan "nie-goedgekeurde persone" is vreemd, o.a. omdat daar geen erkende regulering van wie opgelei kon word, bestaan het nie. Maar dit dui waarskynlik tog op 'n maatreël gemik op 'n mate van beskerming van die beroep teen onvanpaste onderrig.

Die etiese kode soos dit in die res van die Corpus verskyn, is hierbo saamgevat, en verteenwoordig waarskynlik die eindresultaat van iets wat oor eeue heen ontwikkel het. 'n Aspek wat aandag trek is die vermaning om nie diepliggende kankers (Aforisme 6.38) of ander ongeneeslike toestande (Die Kuns c.8) te behandel nie. Dit moet waarskynlik saamgelees word met Epidemies 1.11 wat die geneesheer vermaan om siektes te verlig, mits die pasiënt nie terselfdertyd kwaad aangedoen word nie. Godderis (1997:262-273) meen dat 
die geneesheer inderdaad nie belet word om kroniese, ongeneeslike toestande te behandel nie, en wys op voorbeelde elders in die Corpus waar o.a. been- en gewrigsaandoenings (wat nie volledig geneesbaar is nie) wel behandel word. Die geneesheer mag homself in ieder geval nie onttrek bloot omdat hy meen dat sy onvermoë om volledig te genees, sy reputasie mag skaad nie.

Op treffende wyse word die geneesheer vermaan om as lid van 'n edele beroep vir die pasiënte toeganklik en aanvaarbaar te wees, en eerbaar en fatsoenlik te lewe. Moeite moet gedoen word om siekes volgens hul individuele probleme te benader, en om te konsulteer waar en wanneer nodig. Die kwessie van tariewe moet taktvol hanteer word omdat dit in eie reg die genesingsproses mag beïnvloed. Doeltreffende opleiding is essensieel en in sy verhouding met kollegas moet die geneesheer nie uittartend of vernederend optree nie. In ooreenstemmende trant verwys Soranos (Gin. I.1-5) na die ideale vroedvrou as iemand met 'n onbesproke karakter wat vertroue by pasiënte inboesem, haar vakrigting ken en nie deur bygelowe of bonatuurlike verskynsels beïnvloed word nie.

Die vraag ontstaan in welke mate die geneesheer van die tyd inderdaad die Hippokratiese etos in sy praktyk uitgeleef het, aangesien dit hoegenaamd nie afdwingbaar was nie. Die vraag is moeilik beantwoordbaar, omdat die geneeshere 'n heterogene groep genesers was met ekstreme variasies in die vlak van hul opleiding en praktykvoering. Edelstein (1987:3427) en Godderis (1998:234, 292) meen dat min geneeshere waarskynlik wel streng volgens Hippokratiese standaarde gepraktiseer het, en daar is rede om te glo dat geneeshere in voltydse diens van stadsowerhede waar belastingvrystelling 'n rol gespeel het, moontlik nóg minder eties geleef het as privaatpraktisyns.

In die Hippokratiese boek Voorskrifte c. 6 word daarna verwys dat die arts liefde teenoor sy pasiënt moet betoon, want dit sal ook liefde teenoor die wetenskap meebring. Dit is een van die enigste pertinente verwysings in die Corpus na filantropie. Edelstein (1987:336-340) beweer dan ook dat Hippokratiese geneeskunde aanvanklik nie deur 'n besondere humanisme gekenmerk is nie, maar wel deur tegniese vaardigheid of oorwegings soos status of geldelike voordeel, en dat beroepsriglyne ingestel was op maksimale doeltreffendheid sodat die pasiënt optimale diens kan ontvang. Die geneesheer word dus nie deur humanistiese oorwegings tot uitstekende dienslewering aangespoor nie, maar primêr deur 'n strewe na tegniese vaardigheid. Mettertyd kom daar egter 'n klemverskuiwing, en in die Hellenistiese tyd, deels onder invloed van denkskole soos die Peripatetiese skool, die Empirici en die Metodiste, word 'n filosofiese en meer humanistiese element by die elementêre etiek gevoeg. Die Klassieke era se moraliteit van oorwegend uiterlike optrede word dus aangevul deur 'n innerlike moraliteit, en hiervan getuig Scribonius met sy besonder humanitêre benadering tot etiek - waarskynlik deels onder Stoïsynse invloed. Die etiek-gedeeltes van die Corpus Hippocraticum is waarskynlik in hierdie era geskryf (Lloyd 1950:19). Galenos sit hierdie filantropiese neiging voort, maar toon terselfdertyd 'n verrassende pragmatisme wanneer hy aanvaar dat groot getalle geneeshere nie deur meegevoel vir die medemens aangevuur word nie, maar deur 'n liefde vir geld, eerbetoon en tasbare vergoeding (Edelstein 1987:337, 345346).

Alhoewel die Griekse geneeskunde-etiek soos oorspronklik deur Hippokrates ingestel, met die verloop van tyd aangepas is, bevat dit dus tog 'n element van tydloosheid wat maak dat dit vandag nog in 'n groot mate geldig is (Lloyd 1950:59-60). 


\section{BIBLIOGRAFIE}

Die vertaalde titels van Hippokrates se werke verwys na die volgende werke:

$$
\begin{aligned}
& \text { Voorskrifte }=\text { Praecepta } \\
& \text { Dekorum }=\text { Decorum } \\
& \text { Geneesheer }=\text { Medicus } \\
& \text { Die Kuns = De Arte } \\
& \text { Aforismes = Aphorismoi } \\
& \text { Epidemies = Epidemiae }
\end{aligned}
$$

Die Wet $=$ Lex

Aristotle. 1926. Nicomachean Ethics. Transl. H. Rackham. Loeb Classical Library Vol. XIX. Cambridge. MA: Harvard University Press.

Adams, F 1985. The Oath. The Genuine Works of Hippocrates. London: The Sydenham Society.

Celsus. 1935. On Medicine. Transl. W.G. Spencer. Loeb Classical Library Vol. I. Cambridge. MA: Harvard University Press.

Cicero. 1999. Letters to Atticus. Transl. D.R. Shackleton-Bailey. Loeb Classical Library Vol. XXII. Cambridge. MA: Harvard University Press.

Cilliers, L \& Retief, F P 2003. Galenus: prins of pronker? Akroterion 48:81-88.

Edelstein, L 1987. The Professional Ethics of the Greek Physician. In: O \& C L Temkin (edd.). Ancient Medicine. Selected Papers of L. Edelstein. Baltimore, London: The John Hopkins University Press.

Godderis, J 1997. De beste arts zij ook een filosoof? Peeters.

Hamilton, J S 1986. Scribonius Largus and the Medical Profession. Bull. Hist. Med. 60:209-216.

Hippocrates. 1923. Ancient Medicine. Airs, Waters, Places. Epidemics 1 and 3. The Oath. Precepts. Nutriment. Transl. W H S Jones. Loeb Classical Library Vol. I. Cambridge. MA: Harvard University Press.

Hippocrates. 1923. Prognostic. Regimen in Acute Diseases. The Sacred Disease. The Art. Breaths. Law. Decorum. Physician. Transl. W H S Jones. Loeb Classical Library Vol. II. Cambridge. MA: Harvard University Press.

Hippocrates. 1931. Nature of Man. Regimen in Health. Humours. Aphorisms. Regimen 1-3. Dreams. Transl. W H S Jones. Loeb Classical Library Vol. IV. Cambridge. MA: Harvard University Press.

Jouanna, J 1999. Hippocrates. Vert. M B DeBevoise. Baltimore, London: The John Hopkins University Press.

Lloyd, G E R (ed) 1950. Hippocratic writings. Harmondsworth: Penguin Books.

Longrigg, J 1998. Greek Medicine. From the Heroic to the Hellenistic Age. London: Duckworth \& Co.

Major, R H 1954. A History of Medicine Vol. I. Springfield: Charles Thomas Publishers.

Nutton, V 1988. Murders and Miracles. In: From Democedes to Harvey. Studies in the History of Medicine. London: Variorum Reprints.

Plato. 1924. Laches. Protagoras. Meno. Euthydemus. Trans. W R M Lamb. Loeb Classical Library Vol. II. Cambridge. MA: Harvard University Press.

Plato. 1925. Lysis. Symposium. Gorgias. Loeb Classical Library Vol. III. Cambridge. MA: Harvard University Press.

Plato. 1929. Timaeus. Critias, Cleitophon. Menexenus, Epistles. Transl. R G Bury. Loeb Classical Library Vol. IX. Cambridge. MA: Harvard University Press.

Plato. 1930. The Republic. Books I-V. Transl. P Shorey. Loeb Classical Library Vol. V. Cambridge. MA: Harvard University Press. 
Porter, R 1997. The Greatest Benefit to Mankind. London: Harper Collins.

Retief, F P \& Cilliers, L 2001. The influence of Christianity on Graeco-Roman Medicine up to the Renaissance. Akroterion 46:61-73.

Retief, F P \& Cilliers. L 2000. Hippokrates: feit en fiksie. Geneeskunde 24.10:10-14.

Seneca. 1935. Moral Essays: De Beneficiis. Transl. J W Bassore. Loeb Classical Library Vol. III. Cambridge. MA: Harvard University Press.

Sherwin-White, S M 1978. Ancient Cos. Göttingen.

Soranus. 1956. Gynecology. Transl. O Temkin. Baltimore, London: The John Hopkins University Press.

Van Hooff. A. 1999. Antieke artse en Euthanasie. Hermeneus 71.2:122-127. 